\title{
ENLIGHTENING EDUCATION ON QURANIC PERSPECTIVE
}

\author{
Ahmad Zain Sarnoto \\ Pascasarjana, Institut PTIQ Jakarta, Indonesia \\ ahmadzain@ptiq.ac.id
}

\begin{abstract}
Received: 08-06-2021
\end{abstract}
Revised: 17-08-2021

Accepted: 30-10-2021

\begin{abstract}
This article is to reveal that education is not only dealing with issues of intelligence and thinking, but it is also fully responsible for the development of a student's character. Due to the said reason, it is important to explore such research considering that the mental situation of this nation is clearly correlated with the spirit of national education which has been value-free. Our educational philosophy is indeed intellectual, but our learning strategy is no longer concerned with the mental, moral, and developmental aspects of enlightening thinking skills. Al-Qur'an for Muslims is not a mere religious scripture, but it is also indeed to be an enlightening guide to find some basic principles of education which can then inspire in developing a qualified education. This study uses the Qur'anic literature method as well as descriptive and qualitative research with a library research approach by analyzing Qur'anic verses. This article analyzes the signs of al-Qur'an as the basic framework for building an enlightening education.
\end{abstract}

Keywords: Education, Educational philosophy, Al-Qur'an.

\begin{abstract}
Abstrak
Artikel ini untuk mengungkap bahwa pendidikan sesunggubnya tak hanya berurusan dengan persoalan kecerdasan dan penalaran, namun ia bertanggung jawab penuh pada pembangunan budi pekerti peserta didik. Karena itu penting menjadi bahan kajian karen situasi mental bangsa ini jelas berkorelasi dengan jiwa pendidikan nasional yang selama ini berlangsung bebas nilai (value free). Filosofi pendidikan kita memang mencerdaskan, tetapi strategi pembelajaran kita tak lagi mementingkan aspek mental, moral, dan pengembangan kemampuan berpikir yang mencerabkan. AlQur'an bagi umat Islam tidak hanya sebagai kitab suci keagamaan, namun Jika dikaji lebih mendalam akan menemukan beberapa prinsip dasar pendidikan, yang selanjutnya bisa dijadikan inspirasi untuk dikembangkan dalam rangka membangun pendidikan yang bermutu. Metode yang digunakan dalam penelitian ini adalab metode literatur Al-Qur'an. Jenis penelitian yang digunakan adalah kualitatif yang bersifat deskriptif dengan pendekatan kajian pustaka, analisis ayat-ayat alqur'an. Artikel ini menganalisis isyarat dalam Al-Qur'an untuk dijadikan kerangka dasar membangun pendidikan yang membebaskan.
\end{abstract}

Kata Kunci : Pendidikan, Filsafat Pendidikan, Al-Qur'an 


\section{INTRODUCTION}

Education is basically a part of life that cannot be separated from every individual, since was born, people have been doing learning with their surroundings until old. ${ }^{1}$ In short, every individual need education, education in process changes by following the development of knowledge and technology as well as community culture. In building the quality of human resources, education is very important to realize it. ${ }^{2}$ Quality of education become the main pillar of increasing knowledge and insight that will form the individual character of the strongest generation. Education is also believed to be the liberator of the individual community from being left behind. Quality of education will also produce a smart generation who will appear enlighten in the community and the world. ${ }^{3}$

In the education literature, the concept of liberating education was the idea of Paulo Freire, according to him, liberating education is an effort to liberate each individual from the forms of oppression experienced. ${ }^{4}$

In education, process is a system consisting of various interrelated components, and among the components that supports the success of education is the existence of a goal. ${ }^{5}$ The objective component in the education process is the estuary of educational activities. Likewise in Islam, the Qur'an has given the direction of the goal educational process that every individual Muslim will aim at. In the Qur'an there are many verses that indicate the components of education, including the existence of objective aspect education, so the concept of Al-Qur'an perspective of education which is studied by Muslim intellectuals was born. ${ }^{6}$

Al-Qur'an as a source of divine information that has taught many things to humans, which contains issues of belief, principles of worship, morals, muamalah, politics and principles of knowledge. In terms of development science, the Qur'an has given insight and motivation to humans to examine various natural phenomena created by Allah SWT. AlQur'an as the holy book of Muslims, needs to be internalized in aspects of life, as an effort to form a person who has strong faith, a pious soul, a person who has character and intelligence, thinks forward and independent. ${ }^{7}$

This paper, will discuss the verses of Qur'an related to the perspective of Al-Qur'an education that frees individuals from shirk towards monotheism and enlightens them by having an intelligent mind and strong faith.

1 Ahmad Syafei, “Konsep Pendidik Dalam Perspektif Alquran Dan Hadis," Jurnal Qiroah 8, no. 1 (2018): 124, https:// ejurnal.iiq.ac.id/index.php/qiroah/article/view/51.

2 Ahmad Zain Sarnoto, “Aspek Kemanusiaan Dalam Pembelajaran Humanistik Pada Anak Usia Dini,” Profesi: Jurnal Ilmu Pendidikan Dan Keguruan 6, no. 1 (2017): 11-16, https://jurnal.pmpp.or.id/index.php/profesi/article/view/159.

${ }^{3}$ Bambang Hermanto, "Perekayasaan Sistem Pendidikan Nasional Untuk Mencerdaskan Kehidupan Bangsa," Foundasia 11, no. 2 (2020): 52-59, https://doi.org/10.21831/foundasia.v11i2.26933.

${ }^{4}$ I Komang Ramadi Putra, "PENDIDIKAN MEMBEBASKAN SEBAGAI UPAYA MEWUJUDKAN GENERASI EMAS 2045 (Telaah Pemikiran Kritis Paulo Freire)," Vidya Sambita Jurnal Penelitian Agama VI, no. 1 (2020): 73-84.

5 Isnaini Nur 'Afiifah and Muhammad Slamet Yahya, "Konsep Belajar Dalam Al-Qur' an Surat Al- 'Alaq," Arfannur: Journal of Islamic Education 1, no. 1 (2020): 87-102.

${ }^{6}$ Ahmad Zain Sarnoto, "Metode Komunikasi Yang Ideal Dalam Pendidikan Keluarga Menurut Al-Quran" 9, no. 1 (2021): 105-15, https://doi.org/doi.org/10.36052/andragogi.v9i1.230.

7 Said Agil Husain Almunawar, Aktualisasi Nilai-Nilai Qur'an Dalam Sistem Pendidikan Islam (Ciputat:Ciputat Press, 2005). 


\section{METHOD}

This research uses the Qur'anic literature method and a qualitative descriptive study with a literature study approach by analysing the verses of Al-Qur'an. Data collection in this study was taken from various sources of written materials and then identified and processed into relevant data. ${ }^{8}$ In addition to referring the various reading sources related to research, in the discussion of this material, it refers to several books of interpretation related to material about educational goals in the Qur'an by using the thematic interpretation method. Thematic interpretation or also known as maudu'i interpretation is a pattern of interpretation by focusing on one topic related to a particular problem, then defining the keywords of the problem, and then collecting verses of the Qur'an related to the topic of discussion. ${ }^{9}$

\section{RESULTS AND DISCUSSION}

\section{Findings}

The educational process in Islam aims to form human beings who have noble character, become servants of Allah who are always obedient to serve and prosper the earth as part of social beings. As an obedient servant of God, education is treated as a result of the learning process that produces a straight person and has a strong aqidah, so that he is free from shirk to become a human being, who is physically and spiritually intact and can live naturally by practicing the values of piety.

According to Syed Muhammad Al-Naquib al-Attas, the goal of education in Islam is to create a universal human individual, which have an integrated relationship between submission and obedience to Allah while carrying a mission of salvation for the social environment. Insan Kamil is also understood as a human being who is balanced in quality, thought, dhikr and deeds. ${ }^{10}$

The "Insan Kamil" is a reflection of obedience in worshiping only Allah by purifying monotheism, understanding the purpose and nature of his creation as a human being, this is in line with the word of Allah in the Qur'an Surah Az-Zariat verse 56, which means: And I did not create the jinn and mankind except to worship Me. (Surat 51:56)

The meaning of the verse above is that all activities carried out by humans are oriented to worship Allah SWT. ${ }^{11}$ Therefore, in carrying out life activities, it must be in accordance with what is desired by Allah SWT.

Liberating education on Quranic perspective is essentially caring for the natural values possessed by individual humankinds, so they are maintained and accordance with religious rules and norms, free from the dogmas of shirk, hypocrisy and tyranny. If the individual wants continue to realize his holy nature potential (tawhid), and be free from the shackles of his

\footnotetext{
${ }^{8}$ Nana Syaodih Sukmadinata, Metode Penelitian Pendidikan (Bandung: remaja Rosyda Karya, 2010).

9 Khoirul Ulum and Ahmad Khoirur Roziqin, "Sabar Dalam Al-Qur'an: Kajian Tafsir Maudhui," Jurnal Ilmu Al-Qur'an Dan Hadist 4, no. 1 (2021): 120-42.

${ }^{10}$ Kemas Badaruddin, Filasafat Pendidikan Islam: Analisis Pemikiran Prof. Dr. Syed Muhammad Al-Naquib Al-Attas (Yogyakarta: Pustaka Pelajar, 2009).

${ }^{11}$ M. Quraish Shihab, Wawasan Al-Qur'an: Tafsir Tematike Atas Pelbagai Persoalan (Bandung: Mizan, 1997).
} 
negative desires, then one of efforts is through the education process, which will ultimately increase the power of creative thinking and productive. ${ }^{12}$

\section{Discuusion}

\section{Concept Of Education In The Qur'an}

The concept of education in the Qur'an literature and Islamic education studies are often used words of tarbiyah, taklim, takdib and tazkiyah. The four things basically have in common. Where tarbiyah is the process of guarding, maintaining, developing and guiding students. ${ }^{13}$ While the meaning of taklim is to tell and explain something, then muta'alim (students) know something that was previously unknown and understood. While takdib is defined as planting, coaching and strengthening morals in students (muta'adib) so they have good morals, have faith and fear of Allah SWT. And the fourth is tazkiyah, which means to grow and develop, that is the process of purifying one's soul from worldly things to achieve the pleasure of Allah SW'T. Of the four things, it shows a complementary concept of Islamic Education. $^{14}$

In its development, the term tarbiyah is more widely used by experts in discussing education. According to al-Raghib al-Asfananiy, the word tarbiyah comes from the word rabb which means to grow or develop something gradually to achieve perfection. ${ }^{15}$

Meanwhile, Ahmad D. Marimba as quoted by Saehudin, stated that education is a conscious guidance from educators in Physical and spiritual development of students in order to form a good personality. ${ }^{16}$ Meanwhile, according to Abudin Nata, the word rabbaniy means a person who has perfect knowledge and piety to Allah SWT. Thus, the word rabbaniy can be understood as a person who has perfect and deep knowledge, and contributes with his knowledge to other people and environment. ${ }^{17}$

The Qur'an has motivated humans to seek knowledge, verse that was first revealed, named Surah Al-Alaq from verses 1-5 with the command "iqra" (reading) is evidence of encouragement and support learning motivation demands knowledge. ${ }^{18}$ Al-Qur'an is the word of God which contains various things including the field of Education, which is needed by humans, as a provision for world life towards happiness in the world and the hereafter. ${ }^{19}$

The main foundation in building Islamic education is Al-Qur'an, various terms of educational cues in it include tarbiyah, taklim, takdib and tazkiyah with different meanings that

12 Saihu et al., "Design of Islamic Education Based on Local Wisdom (An Analysis of Social Learning Theories in Forming Character through Ngejot Tradition in Bali)," International Journal of Advanced Science and Technology 29, no. 6 (2020), http://sersc.org/journals/index.php/IJAST/article/view/11802.

13 HM Suyudi, Pendidikan Dalam Perspektif Al Qur'an: Integrasi Epistemologi Bayani, Burhani Dan Irfani (Yogyakarta: MIKRAJ, 2014).

${ }_{14}$ Mikyal Hardiyati and Umi Baroroh, "Pendidikan Perspektif Al-Quran ( Studi Tafsir Tarbawi Karya Ahmad Munir )," Jurnal Pendidikan 13, no. 1 (2019): 108-13.

${ }^{15}$ Hardiyati and Baroroh.

16 Ahmad Izzam Saehudin, Tafsir Pendidikan Studi Ayat-Ayat Berdimensi Pendidikan (Banten:Shuhuf Media Insani, 2012).

17 Abudin Nata, Tafsir Ayat-Ayat Pendidikan: Tafsir Al-Ayat Al-Tarbawiy (Jakarta: Rajawali Press, 2017).

18 Putri Maria Ulvah, "Kajian Tafsir Surat Al-'Alaq Ayat 1-5 Dalam Kitab Al Munir Dengan Metode Tafsir Konvensional Dan Kontekstualisasinya Pada Zaman Sekarang," Jurnal Ilmiah Mahasiswa Raushan Fiker 7, no. 2 (2018): 219-27, https://doi.org/10.24090/jimrf.v7i2.2520.

${ }_{19}$ Rahman Afandi, “Tujuan Pendidikan Nasional Perspektif Al-Quran,” Jurnal INS ANLA 16, no. 3 (2011): 3. 
complement each other. Thus, the purpose of education in Islam is to gain knowledge so there is a change towards moral improvement, to create human beings who are obedient to serve Allah SWT. ${ }^{20}$

Although Islamic education experts have different opinions about the meaning of education in the Qur'an, they are not changing the meaning of the concept education itself, for example the meaning of tarbiyah is more to shape behavior, taklim leads to develop intellectual aspects, while takdib develops behavioural aspects, and tarkiyah focuses on aspects of mental education. In general, the purpose of education on Quranic perspective is to educate, teach, foster and direct human individuals to carry out their functions as servants of Allah (Abdullah) and as His caliph (representative), which is carrying out human functions requires knowledge.

\section{Enlightening education on Quranic perspective}

Education is essentially aim to develop the potential possessed by humans and psychic functions through the stages of the learning process to achieve perfection of independence and maturity. ${ }^{21}$ Enlightening education on Quranic perspective is study of Educational Signs, where the first revelation to the Messenger of Allah was Surah Al-'Alaq verses 1-5 which contains important and basic information for humans regarding the command to read as a process of learning in education.

Surah Al-'Alaq is the 96th surah that consist of 19 verses, the first revealed were verses 1 to 5, which means: 1) Read (o prophet) in the name of your Lord who created, 2) He created man from a clinging clot, 3) Read, and your Lord is the Most Generous, 4) Who taught (humans) by the pen, 5) Taught man that which he knew not. ${ }^{22}$

In the first verse Allah SWT ordered "iqra" (read) using a command sentence (fi'il amar), according to Buya Hamka the command to read in the first verse of Surah Al-Alaq is an order to the Prophet and all his followers to "iqra" read in the name of Allah, God who created. ${ }^{23}$

Meanwhile, Quraish Shihab argued that why the first commandment addressed to the Prophet was to read, even though he was an ummi (not good at reading and writing). Because Iqra is a root word that means to collect, iqra does not always mean reading written texts with certain letters. From the meaning of iqra (collecting) various meanings were born, including conveying, exploring, studying, researching and reading, in written or unwritten texts. ${ }^{24}$

When the prophet was ordered by the angel Gabriel to read, "Iqra" (read), the prophet replied "ma aqra?" (what to read). This question is not answered, the wisdom is that Allah SWT wants the Prophet and his people to read anything, as long as reading accompanied by bismi rabbi (calling the name of Allah), in the sense of learning to read and knowledge that brings benefits to mankind. ${ }^{25}$

${ }^{20}$ Dedeng Rosidin, Pendidikan Dalam Al-Quran:Kajian Tematik Dan Semantik (Bandung:Insan Rabbani, 2015).

21 Ahmad Syafi'i, "KONSEP PENDIDIK DALAM PERSPEKTIF ALQURAN DAN HADIS," Qiroah 1, no. 1 (2018): 1-24.

${ }^{22}$ Kementerian Agama, Tafsir Ringkas Kemenag, ed. Muchlis M. Hanafi (Jakarta: Jakarta: Kementerian Agama RI dan Pusat Studi Al-Qur'an (PSQ), 2016).

23 'Afiifah and Yahya, "Konsep Belajar Dalam Al-Qur' an Surat Al- 'Alaq."

${ }_{24}$ M. Quraish Shihab, Tafsir Al Misbah: Pesan, Kesan Dan Keserasian Al Quran (Volume 15, Juz Amma), V (Jakarta: Lentera Hati, 2006).

${ }_{25}$ Mohamad Nur Fuad, "Nilai Surah Al-Alaq Dalam Kehidupan," An-Nida" : Jurnal Prodi Komunikasi Penyiaran Islam, 2015, 85-109. 
Reading activities for Muslims are part of the educational process which is very useful in opening the horizons of human beings, reading is the beginning the process of intellectual exploration in search of truth and knowledge, so it will strengthen their faith in Allah SWT. ${ }^{26}$ The command to read "iqra" in various contexts is reading, researching, exploring, knowing something, reading nature, signs of the times, history and other sciences. ${ }^{27}$

In the second verse, Allah says which means: He has created man from a clinging clot, according to Hamka, ${ }^{28}$ the process of creating human beings is the second stage from a clot after nuthfah, and from a clinging clot the next process becomes flesh (mudhghah). The Prophet Muhammad was not good at reading and writing, but Jibril still urged him to read up to three times, this is a sign that later the prophet will be able to read and memorize the verses of Allah brought by the angel Jibril, because of the Qur'an itself means reading. ${ }^{29}$ Shaykh Muhammad Abdul in his Juz amma interpretation as quoted by Hamka, ${ }^{30}$ explains that Allah Almighty has made humans through the process of semen, turned into blood and become whole humans, with His power Allah will be able to make ummi servants into human beings. moreover, the prophet is a chosen human who occupies the predicate of insan kamil (perfect human). The lesson of the process revelation of the first verse in the Qur'an for Muslims is that all efforts to seek knowledge by reading must be based on the name of Allah. ${ }^{31}$

Whereas in the third verse, "Read, and your Lord is the Most Gracious, according to Hamka, after the first verse that prophet Muhammad was ordered to read in the name of Allah who created man by the process of a clinging clot, followed by reading in the name of God, and God who is meant, of course, is Allah, the Most Noble, Most Gracious and Merciful to all the creatures He created. From this explanation, it can be understood that Allah SWT gives a signal to humans to realize that their potential to be able to read and research, that is a gift from Allah SWT. The knowledge gained from the process of reading and researching and studying the verses of Allah SWT must be implemented in life, and a reflection of people who have intelligence but have a religious character. Every Muslim should have belief that intelligence possessed is an emanation from Allah SWT. All-Knowing and AllKnowing. ${ }^{32}$

In the fourth verse Allah says: "Who taught (humans) by the pen", according to Hamka, this is where Allah SWT as God shows His Most High Privileges and Glory, by teaching humans' various knowledge and opening it to Him. He gave key to the store of knowledge with qalam. With the qalam (pen) in addition to the tongue used for reading, Allah SW'T also stipulates that with the qalam (pen) knowledge can be recorded. ${ }^{33}$

\footnotetext{
${ }^{26}$ Handoko, Edi Saputra, and Zulheddi, "Nilai-Nilai Pendidikan Dalam Alquran Surat Al-Alaq," Handoko: Nil 2, no. 1 (2018): 81-95, https://doi.org/10.29240/bjpi.v2i2.304.

27 Muhammad Julkarnain, "Fragmentasi Tafsir Surah Al-'Alaq Berbasis Kronologi (Studi Atas Fahm AlQur'an Al-Hakim: Al-Tafsir Al-Wadhih Hasb Tartib Al-Nuzul Karya Muhammad 'Abid Al-Jabiri)," Religia 18, no. 2 (2015): 129, https://doi.org/10.28918/religia.v18i2.625.

${ }^{28}$ Hamka, Tafsir Al-Azhar Jilid 9 (Juz 28, 29, 30), Cet. 1 (Jakarta: Jakarta : Gema Insani, 2015).

${ }^{29}$ Shihab, Tafsir Al Misbah: Pesan, Kesan Dan Keserasian Al Quran (Volume 15, Juz. Amma).

${ }^{30}$ Hamka, Tafsir Al-Azhar Jilid 9 (Juz, 28, 29, 30).

${ }^{31}$ Rusdin, "INSAN KAMIL DALAM PERSPEKTIF MUHAMMAD IQBAL," Rausyan Fiker 12, no. 2 (2016).

32 Sayyed Hoesein Nasr, Horison Baru Pendidikan Islam ((Jakarta: Tp, 2005).

${ }^{33}$ Hamka, Tafsir Al-Azhar Jilid 9 (Juz 28, 29, 30).
} 
While in the fifth verse, Allah says which means: "Taught man that which he knew not.", according to Hamka, ${ }^{34}$ Allah SWT first teaches humans through the qalam. And after being able to use qalam (pen) there will be a lot of knowledge given by Allah SWT to humans, so the knowledge will develop. Basically, the content of Surah Al-Alaq has provided an overview of the education elements, and the results of educational process will be born many intellectuals who have a solid faith, so the knowledge that they have will provide to enlighten themselves and their environment.

\section{CONCLUSION}

Education in Islam is to make humans who are free from shirk towards monotheism to become human beings that free from negative impulses. enlightening education on Quranic perspective is the introduction of various phenomena by means of reading, researching, studying, as the first verse was revealed with the command "iqro" (reading as to make intelligent Muslim who have the ability to think rationally.

\section{REFERENCES}

'Afiifah, Isnaini Nur, and Muhammad Slamet Yahya. "Konsep Belajar Dalam Al-Qur' an Surat Al- 'Alaq.” Arfannur: Journal of Islamic Education 1, no. 1 (2020): 87-102.

Afandi, Rahman. "Tujuan Pendidikan Nasional Perspektif Al-Quran." Jurnal INSANLA 16, no. 3 (2011): 3 .

Agama, Kementerian. Tafsir Ringkas Kemenag. Edited by Muchlis M. Hanafi. Jakarta: Jakarta: Kementerian Agama RI dan Pusat Studi Al-Qur'an (PSQ), 2016.

Almunawar, Said Agil Husain. Aktualisasi Nilai-Nilai Qur'an Dalam Sistem Pendidikan Islam. Ciputat:Ciputat Press, 2005.

Badaruddin, Kemas. Filasafat Pendidikan Islam: Analisis Pemikiran Prof. Dr. Syed Mubammad AlNaquib Al-Attas. Yogyakarta: Pustaka Pelajar, 2009.

Fuad, Mohamad Nur. "Nilai Surah Al-Alaq Dalam Kehidupan." An-Nida": Jurnal Prodi Komunikasi Penyiaran Islam, 2015, 85-109.

Hamka. Tafsir Al-Azhar Jilid 9 (Juz 28, 29, 30). Cet. 1. Jakarta: Jakarta: Gema Insani, 2015.

Handoko, Edi Saputra, and Zulheddi. "Nilai-Nilai Pendidikan Dalam Alquran Surat Al-Alaq." Handoko: Nil 2, no. 1 (2018): 81-95. https://doi.org/10.29240/bjpi.v2i2.304.

Hardiyati, Mikyal, and Umi Baroroh. "Pendidikan Perspektif Al-Quran ( Studi Tafsir Tarbawi Karya Ahmad Munir )." Jurnal Pendidikan 13, no. 1 (2019): 108-13.

Hermanto, Bambang. "Perekayasaan Sistem Pendidikan Nasional Untuk Mencerdaskan Kehidupan Bangsa." Foundasia 11, no. 2 (2020): 52-59. https://doi.org/10.21831/ foundasia.v11i2.26933.

Julkarnain, Muhammad. 'Fragmentasi Tafsir Surah Al-'Alaq Berbasis Kronologi (Studi Atas Fahm Al-Qur'an Al-Hakim: Al-Tafsir Al-Wadhih Hasb Tartib Al-Nuzul Karya Muhammad 'Abid Al-Jabiri)." Religia 18, no. 2 (2015): 129. https://doi.org/10.28918/religia.v18i2.625.

\footnotetext{
${ }^{34}$ Hamka.
} 
Nasr, Sayyed Hoesein. Horison Baru Pendidikan Islam. (Jakarta: Tp, 2005.

Nata, Abudin. Tafsir Ayat-Ayat Pendidikan: Tafsir Al-Ayat Al-Tarbawiy. Jakarta: Rajawali Press, 2017.

Putra, I Komang Ramadi. "PENDIDIKAN MEMBEBASKAN SEBAGAI UPAYA MEWUJUDKAN GENERASI EMAS 2045 (Telaah Pemikiran Kritis Paulo Freire).” Vidya Sambita Jurnal Penelitian Agama VI, no. 1 (2020): 73-84.

Rosidin, Dedeng. Pendidikan Dalam Al-Quran:Kajian Tematik Dan Semantik. Bandung:Insan Rabbani, 2015.

Rusdin. "INSAN KAMIL DALAM PERSPEKTIF MUHAMMAD IQBAL." Rausyan Fikr 12, no. 2 (2016).

Saehudin, Ahmad Izzam. Tafsir Pendidikan Studi Ayat-Ayat Berdimensi Pendidikan. Banten:Shuhuf Media Insani, 2012.

Saihu, A. Aziz, F. Mubin, and Ahmad Zain Sarnoto. "Design of Islamic Education Based on Local Wisdom (An Analysis of Social Learning Theories in Forming Character through Ngejot Tradition in Bali)." International Journal of Advanced Science and Technology 29, no. 6 (2020). http://sersc.org/journals/index.php/IJAST/article/view/11802.

Sarnoto, Ahmad Zain. "Aspek Kemanusiaan Dalam Pembelajaran Humanistik Pada Anak Usia Dini." Profesi: Jurnal Ilmu Pendidikan Dan Keguruan 6, no. 1 (2017): 11-16. https://jurnal.pmpp.or.id/index.php/profesi/article/view/159.

_. "Metode Komunikasi Yang Ideal Dalam Pendidikan Keluarga Menurut Al-Quran" 9, no. 1 (2021): 105-15. https://doi.org/doi.org/10.36052/andragogi.v9i1.230.

Shihab, M. Quraish. Tafsir Al Misbab: Pesan, Kesan Dan Keserasian Al Quran (Volume 15, Juz Amma). V. Jakarta: Lentera Hati, 2006.

- Wawasan Al-Qur'an: Tafsir Tematik Atas Pelbagai Persoalan. Bandung: Mizan, 1997.

Sukmadinata, Nana Syaodih. Metode Penelitian Pendidikan. Bandung: remaja Rosyda Karya, 2010.

Suyudi, HM. Pendidikan Dalam Perspektif Al Qur'an: Integrasi Epistemologi Bayani, Burbani Dan Irfani. Yogyakarta: MIKRAJ, 2014.

Syafei, Ahmad. "Konsep Pendidik Dalam Perspektif Alquran Dan Hadis.” Jurnal Qiroah 8, no. 1 (2018): 1-24. https:// jurnal.iiq.ac.id/index.php/qiroah/article/view/51.

Syafi'i, Ahmad. "KONSEP PENDIDIK DALAM PERSPEKTIF ALQURAN DAN HADIS." Qiroah 1, no. 1 (2018): 1-24.

Ulum, Khoirul, and Ahmad Khoirur Roziqin. "Sabar Dalam Al-Qur'an: Kajian Tafsir Maudhui." Jurnal Ilmu Al-Qur'an Dan Hadist 4, no. 1 (2021): 120-42.

Ulvah, Putri Maria. "Kajian Tafsir Surat Al-'Alaq Ayat 1-5 Dalam Kitab Al Munir Dengan Metode Tafsir Konvensional Dan Kontekstualisasinya Pada Zaman Sekarang." Jurnal Ilmiah Mahasiswa Raushan Fiker 7, no. 2 (2018): 219-27. https://doi.org/10.24090/jimrf.v7i2.2520. 